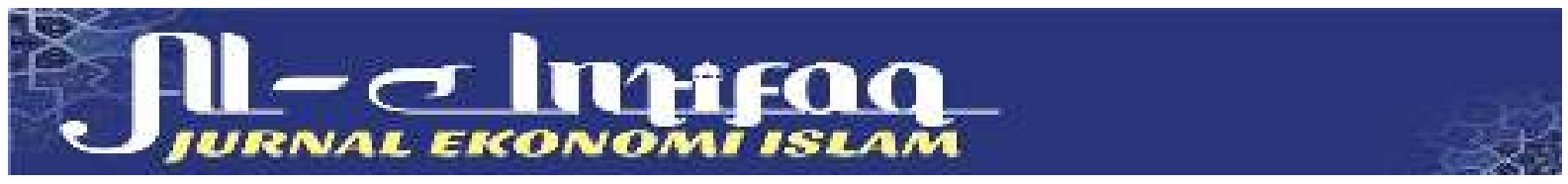

\title{
Sistem Bagi Hasil Kebun Aren Dalam Perspektif Ekonomi Syariah Di Nagari Andaleh Baruh Bukik Kecamatan Sungayang Kabupaten Tanah Datar
}

\author{
Himyar Pasrizal ${ }^{1}$, Rahmat Firdaus ${ }^{2}$, Mirawati ${ }^{3}$ \\ Fakultas Ekonomi dan Bisnis Islam IAIN Batusangkar \\ himyar.pasrizal@ianbatusangkar.ac.id ${ }^{1}$, firdausrahmat157@gmail.com², \\ mirawati@iainbatusangkar.ac.id ${ }^{3}$
}

\begin{abstract}
From the research conducted by the author in the field, it can be concluded that the distribution system for the palm plantation in Nagari Andaleh Baruh Bukik consists of the first three types of profit sharing with a ratio of 50\%: 50\%, a system of help, and a system of profit sharing with a ratio of $70 \%$. : 30\%. Profit sharing is carried out between the owner and cultivator of the palm plantation in Nagari Andaleh Baruh Bukik which has been mutually agreed to contain gharar and there is injustice in the distribution of the results from the palm tree (enau). Should every yield obtained from the palm tree (enau) cultivators must explain in detail to the owner about the results obtained. Every result obtained by the owner is also entitled to get results, such as selling fruit tabs, selling palm fibers, selling leaves and sticks of palm branches, and selling palm stems. So that the occurrence of an action that has taken the rights of others in the form of unfair distribution of results. This is evident when the distribution of the yield from the palm plantation often occurs problems caused by inconsistencies with what was agreed at the beginning with the results obtained between the cultivator and the owner.
\end{abstract}

Keywords: System, profit sharing, Sharia economy

\begin{abstract}
Abstrak: Dari penelitian yang penulis lakukan di lapangan dapat disimpulkan bahwa, sistem pembagian hasil kebun aren yang ada di Nagari Andaleh Baruh Bukik terdiri dari tiga macam pertama bagi hasil dengan nisbah 50\%:50\%, sistem tolong menolong, dan sistem bagi hasil dengan nisbah 70\%:30\%. Bagi hasil dilakukan antara pemilik dan penggarap kebun aren di Nagari Andaleh Baruh Bukik yang telah disepakati secara bersama mengandung gharar dan adanya ketidakadilan dalam pembagian hasil dari pohon aren (enau). Seharusnya setiap hasil yang diperoleh dari pohon aren (enau) penggarap harus menjelaskan secara rinci kepada pemilik tentang hasil yang diperoleh. Setiap hasil yang diperoleh pemilik juga berhak mendapatkan hasilnya seperti penjualan buah tab, penjualan ijuk, penjualan daun dan lidi dahan enau, dan penjualan batang enau. Sehingga terjadinya suatu tindakan yang telah mengambil hak orang lain dalam bentuk ketidakadilan pembagian hasil. Hal itu terbukti pada saat pembagian hasil kebun aren sering kali terjadi persoalan yang disebabkan oleh ketidaksesuain dengan yang di sepakati di awal dengan hasil yang diperoleh antara penggarap dengan pemilik.
\end{abstract}

Kata Kunci : Sistem, bagi hasil, ekonomi Syariah

\section{PENDAHULUAN}

Secara garis besar ciri khas ekonomi yang berlandasan al-qur'an terletak pada dua aspek yaitu aspek sumber pemikiran dan aspek isi aspek pemikiran meliputi sumber wahyu (naqly) dan sumber sain (aqly atau ijtihad). Aspek ini mempunyai dua komponen yang 
saling terkait dan tidak di pisahkan yaitu komponen tata nilai dan komponen sumber daya ekonomi yang apabila dipandukan diantara keduanya sesuai dengan ajaran Islam yang bersumber dari al-qur'an dan al-sunnah, maka akan terbentuk suasana hidup yang harmonis dengan adanya keselarasan, keserasian, dan keseimbangan. (Nazeri.2016)

Selain landasan hukum pokok ada juga landasan hukum yang bersifat melengkapi, seperti qiyas dan ijma' yang mana pada dasarnya kedua hal ini juga merujuk dari Al-Qur'an dan As-Sunnah. Hukum-hukum yang mendasari berbagai kegiatan transaksi berbasis ekonomi syariah sepenuhnya dijalankan untuk kemaslahatan masyarakat. Kesejahteraan masyarakat dalam perekonomian syariah tidak diukur dari aspek-aspek nyata atau materil, namun juga dapat mempertimbangkan dampaknya pada lingkungan, serta dampak berupa sosial, mental dan spritual. Ekonomi syariah memiliki tujuan untuk meraih falah, yang dimaksud dengan falah adalah kesuksesan yang hakiki berupa kebahagiaan dalam segi materiil dan spritual serta tercapai kesejahteraan dunia akhirat. Dalam melaksanakan sistem perekonomian syariah memiliki beberapa prinsip-prinsip perekonomian yang harus dipenuhi seperti segala macam sumber daya yang ada dipandang sebagai titipan atau pemberian dari Allah SWT kepada mahluknya dan perekonomian syariah menolak adanya akumulasi kekayaan yang hanya dapat dikuasai oleh segelintir orang saja. (N.A Islaliha, Frita.N, Maulana.R 2019)

Kerja sama dalam usaha pertanian ada berbagai macam istilah yaitu muzara'ah, mukhabarah, dan musaqah. Muzara'ah merupakan kerja sama pengolahan pertanian antara pemilik lahan dan penggarap, dimana pemilik lahan memberikan lahan pertanian kepada si penggarap untuk ditanami dan dipelihara dengan imbalan bagian tertentu dari hasil panen tersebut. Mukhabarah merupakan bentuk kerja sama antara pemilik sawah atau tanah dan penggarap dengan perjanjian bahwa hasilnya akan dibagi antara pemilik tanah dan penggarap menurut kesepakatan bersama sedangkan biaya dan benihnya di tanggung oleh penggarap tanah. Musaqah merupakan bentuk yang lebih sederhana dari muzara'ah dimana si penggarap hanya bertanggung jawab atas penyiraman dan pemeliharaan. Sebagai imbalan, si penggarap berhak atas nisbah tertentu dari hasil panen tersebut. (A. Kartiko 2019)

Kabupaten Tanah Datar memiliki 14 Kecamatan dan 72 Nagari pada umumnya Kabupaten Tanah Datar sudah melakukan sistem bagi hasil dalam usahanya, salah satu Nagari yang sudah melakukan sistem bagi hasil adalah Nagari Andaleh Baruh Bukik. Nagari Andaleh Baruh Bukik merupakan salah satu Nagari yang termasuk dalam Kecamatan Sungayang, Kabupaten Tanah Datar, Provinsi Sumatera Barat. Nagari Andaleh Baruh Bukik terletak kurang lebih 10 KM dari Batusangkar, Ibu Kota dari Kabupaten Tanah Datar. Nagari Andaleh Baruh Bukik mempunyai bentuk wilayah yang landai sampai sangat curam. Penggunaan lahanya terdiri dari hutan, semak belukar, sawah, pemukiman. Kondisi geografis nagari Andaleh Baruh Bukik terdiri dari perbukitan dan pergunungan dengan ketinggian 700-1700 meter dari permukaan laut. Sebagian besar mata pencarian Nagari Andaleh Baruh Bukik adalah pertanian.

Masyarakat Nagari Andaleh Baruh Bukik lebih dominan bertani anau. Adapun daftar masyarakat yang mempunyai kebun enau antara lain:

Tabel 1

Daftar Masyarakat Yang Mempunyai Kebun Anau

Di Nagari Andaleh Baruh Bukit Dari Tahun 2016-2020

\begin{tabular}{|c|c|c|c|}
\hline TAHUN & PEMILIK & TAHUN & PENGGARAP \\
\hline 2016 & 105 & 2016 & 209 \\
\hline 2017 & 209 & 2017 & 275 \\
\hline 2018 & 210 & 2018 & 270 \\
\hline
\end{tabular}




\begin{tabular}{|l|l|l|l|}
\hline 2019 & 189 & 2019 & 259 \\
\hline 2020 & 250 & 2020 & 278 \\
\hline
\end{tabular}

Sumber: Kantor wali Nagari Andaleh Baruh Bukik

Berdasarkan tabel 1.1 di atas dapat dijelaskan bahwa jumlah pemilik kebun enau di Nagari Andaleh Baruh Bukik pada tahun 2016 sebanyak 105 orang dan penggarapnya sebanyak 209 orang, pada tahun 2017 pemilik kebun enau sebanyak 209 dan penggarapnya sebanyak 275, pada tahun 2018 pemilik kebun enau sebanyak 210 dan penggarap sebanyak 270, pada tahun 2019 pemilik kebun enau sebanyak 189 dan penggarapnya sebanyak 259, pada tahun 2020 pemilik kebun enau sebanyak 250 dan penggarapnya 278. Adapun daftar jumlah masyarakat yang menggunakan sistem bagi hasil 70\%:30\%, 50\%:50\%, dan sistem tolong-menolong.

Tabel 2

Jumlah Masyarakat yang Menggunakan Sistem Bagi Hasil 70:30\%, 50:50\%, dan Sistem Tolong-Menolong

\begin{tabular}{|c|c|c|c|c|c|}
\hline \multirow{2}{*}{ No } & \multirow{2}{*}{$\begin{array}{c}\text { Jumlah } \\
\text { masyarakat } \\
\text { bertani enau }\end{array}$} & \multirow{2}{*}{$\begin{array}{c}\text { Jumlah } \\
\text { batang } \\
\text { enau }\end{array}$} & \multicolumn{2}{|c|}{ Nisbah Bagi Hasil } & Sistem tolong \\
\cline { 4 - 5 } & & $\mathbf{7 0} \mathbf{3 0} \%$ & $\mathbf{5 0 : 5 0 \%}$ & \\
\hline 1. & 25 & 264 & $\checkmark$ & & \\
\hline 2. & 10 & 197 & & $\checkmark$ & \\
\hline 3. & 5 & 84 & & & $\checkmark$ \\
\hline
\end{tabular}

Wawancara dengan masyarakat petani enau, 1 November 2020. Di Nagari Andaleh Baruh Bukik

Berdasarkan tabel 1.2 di atas dapat dijelaskan bahwa jumlah masyarakat yang menggunakan sistem bagi hasil 70:30\% sebanyak 25 orang dengan jumlah batang enaunya sebanyak 264 batang, jumlah masyarakat yang menggunakan sistem tolong menolong sebanyak 5 orang dengan jumlah batang enaunya sebanyak 84 batang, dan jumlah masyarakat yang menggunakan sistem bagi hasil 50\%:50\% sebanyak 10 orang dengan jumlah batang enaunya sebanyak 197 batang. Batang enau ini dijual dengan melakukan dua transaksi yaitu pertama, jual beli murni yang mana 1 batang enau dijual seharga Rp 100.000 sampai batang enau itu tidak berfungsi lagi (mati), kedua pola bagi hasil dengan nisbah 70\%:30\%, 50\%:50\%, dan sistem tolong menolong. Secara umum pola bagi hasil yang banyak berlaku di Nagari Andaleh Baruh Bukik untuk perhitungan batang anau tersebut adalah 70\%:30\% namun pola bagi hasil dengan nisbah 70\%:30\% itu kurang cocok dilakukan karena sangat merugikan pihak pemilik lahan, apabila dikolkulasikan dengan hasil yang didapat oleh penggarap dalam 1 batang enau itu dapat menghasilkan 10 mayang, dalam 1 mayang itu bisa mendapatkan penghasilan gula aren seharga 2.000 .000 perbulan.

\section{KAJIAN TEORI}

\section{Konsep Bagi Hasil}

Bagi hasil merupakan suatu sistem dimana dilakukannya pejanjian atau ikatan bersama dalam melakukan suatu kegiatan usaha. Kerja sama yang diharapkan nanti akan membawa keuntungan terhadap kedua bela pihak, disamping itu bagi hasil sebagai aturan yang mengatur antara pemilik lahan dan pengelola lahan dalam suatu usaha yang mana akan mendapatkan persentase antara kedua belah pihak sesuai dengan kesepakatan bersama pada waktu akad berlangsung, sehingga tidak ada unsur penipuan dan kezaliman didalamnya. Bagi hasil tersebut akan menjauhkan orang-orang yang bekerja sama dari penipuan dan kezaliman yang dilarang oleh agama Islam. (W. Wahab 2016)

Bagi hasil dalam pertanian dapat dijelaskan beberapa bentuk yaitu:

1. Muzara'ah 
Muzara'ah menurut bahasa, Al-muzara'ah memiliki dua arti, yang pertama $A L-$ muzara'ah yang berarti Tharh Al-Zur'ah (melemparkan tanaman), maksudnya adalah modal (Al-Hadzar). Makna yang pertama adalah makna majaz dan makna yang kedua ialah makna hakiki. Secara etimologis berasal dari kata az-zar'u yang berarti penanaman atau pengolahan. Adapun muzara'ah secara terminologis adalah kerja sama suatu pengolahan pertanian antara pemilk lahan dan penggarap, dimana pemilik lahan memberikan lahan pertaniannya kepada si penggarap untuk ditanami dan dipelihara dengan imbalan bagian tertentu (persentase) dari hasil panen. (D. Mardani 2012, 20)

\section{Mukhabarah}

Mukhabarah adalah salah satu muamalah yang akadnya memiliki kesamaan dengan muzara'ah baik dalam hal dasar hukum, syarat, dan rukunnya. Keduanya masih sama-sama dalam perdebatan para ulama. Ada sebagian ulama yang membolehkan dan ada sebagian ulama yang tidak membolehkannya. Namun, dilihat dari sisi manfaat yang diambil dari kedua akad tersebut maka secara syarat baik mukhabarah dan muzara'ah boleh dilakukan sepanjang tidak ada maksud mencari keuntungan untuk diri sendirinya dan upaya mempekerjakan orang lain tanpa diberi upah sedikitpun dari hasil kerjanya.

Perbedaan antara muamalah yang bersifat mukhabarah dan muzara'ah terletak dalam benih yang akan ditanam apakah benih menjadi tanggungan pemilik tanah atau menjadi tanggungan penggarap. Dalam akad muzara'ah, pihak penggarap adalah yang menyediakan benih, sedangkan pada akad mukhabarah, pemilik tanah adalah pihak yang menyediakan benih.

Beberapa ketentuan yang perlu diperhatikan dalam akad mukhabarah, antara lain:

a. Para akid adalah mereka yang sudah cukup dewasa.

b. Usahakan penggarap adalah seagama.

c. Tanah garapan itu betul-betul dapat menghasilkan dan menguntungkan.

d. Akad mukhabarah harus jelas, tidak ada keraguan dan kecurangan.

Hikmah yang dapat kita raih dalam melangsungkan akad muamalah yang bersifat mukhabarah antara lain sebagai berikut:

a. Membuat suatu peluang kerja.

b. Mendidik manusia agar lebih memahami tentang ilmu pertanian dan kerja yang profesional.

c. Saling menghargai antara pemilik tanah dan penggarap tanah sangat mulia dan diridai Allah SWT.

d. Memberi pelajaran agar manusia rajin bekerja (Darwis 2016)

\section{Musaqah}

Musaqah secara etimologi, musaqah berarti suatu transaksi dalam pengairan yang oleh penduduk Madinah yang disebut dengan al-mu'amalah. Secara terminologis fiqh, musaqah didefinisikan oleh para ulama fiqh dengan: "Penyerahan sebidang kebun pada petani untuk digarap dan dirawat dengan ketentuan bahwa petani mendapatkan suatu bagian dari hasil kebun itu." Ulama Syafi'iyah mendefinisikannya dengan: "Mempekerjakan petani penggarap untuk menggarap kurma atau pohon anggur saja dengan cara mengairi dan merawatnya dan hasil kurma atau anggur itu dibagi bersama antara pemilik lahan dengan petani penggarap."

Dengan demikian, akad musaqah adalah bentuk dari kerjasama antara pemilik kebun dengan petani penggarap dengan tujuan agar kebun itu dipelihara dan dirawat sehingga memberikan hasil yang maksimal. Jumhur ulama fiqh, termasuk 
Abu Yusuf dan Muhammad ibn al-Hasan asy-Syaibani, keduanya tokoh fiqh Hanafi, berpendirian bahwa akad musaqah dibolehkan yang bersumber dari sebuah hadits dari 'Abdullah ibn 'Umar yang menyatakan: "Bahwa Rasulullah SAW melakukan kerjasama perkebunan dengan penduduk Khaibar dengan suatu ketentuan bahwa mereka mendapatkan sebagian dari hasil kebun atau pertanian itu."(HR. al-Jama'ah mayoritas pakar hadits).

Ulama Hanafiyah berpendirian bahwa yang menjadi rukun dalam akad musaqah adalah ijab dari pemilik tanah perkebunan dan qabul dari petani penggarap, dan suatu pekerjaan dari pihak petani penggarap. Sedangkan jumhur ulama yang terdiri dari ulama Malikiyah, Syafi'iyah, dan Hanabilah berpendirian bahwa suatu transaksi musaqah harus memenuhi lima rukun, yaitu:

a. Dua orang atau pihak yang melakukan transaksi.

b. Tanah yang dijadikan obyek musaqah.

c. Jenis usaha yang akan dilakukan petani penggarap.

d. Ketentuan mengenai pembagian hasil musaqah.

e. Shigat (ungkapan) ijab dan qabul.

Adapun syarat-syarat yang harus dipenuhi oleh masing-masing rukun adalah:

a. Kedua belah pihak yang melakukan transaksi musaqah orangnya harus cakap bertindak hukum, yakni dewasa baligh, dan berakal.

b. Obyek musaqah itu harus terdiri atas pepohonan yang mempunyai buah.

c. Tanah itu diserahkan sepenuhnya kepada petani penggarap setelah akad berlangsung untuk digarapi, tanpa campur tangan pemilik tanah.

d. Hasil yang dihasilkan dari kebun itu merupakan hak mereka bersama, sesuai dengan kesepakatan yang mereka buat, baik dibagi dua, dibagi tiga, dan sebagainya.

e. Lamanya perjanjian itu harus jelas.

Pelaksanaan musaqah dalam fiqh yaitu tugas penggarap berkewajiban menyiram, menurut Imam Nawawi adalah mengerjakan apa saja yang dibutuhkan pohon-pohon dalam rangka pemeliharannya untuk mendapatkan buah. Di tambahkan pula untuk setiap pohon yang berbuah musiman diharuskan menyiram, membersihkan saluran air, mengurus pertumbuhan pohon, memisahkan pohonpohon yang merambat, memelihara buah, dan perintisan batangnya. Maksudnya memelihara asalnya (pokoknya) dan tidak berulang setiap tahun adalah pemeliharaan hal-hal tertentu yang terjadi sewaktu-waktu, seperti membangun pematang, menggali sungai, mengganti pohon- pohon yang rusak atau pohon yang tidak produktif adalah kewajiban pemilik tanah dan pohon-pohonnya.

Ada orang kaya memiliki tanah yang ditanami pohon kurma dan pohonpohon yang lain, tetapi ia tidak mampu untuk mengelola dan menggarap pohon tersebut karena ada suatu halangan. Maka Allah SWT yang maha bijaksana memperbolehkan orang itu mengadakan suatu perjanjian dengan orang yang mampu mengelola serta menggarapnya dan masingmasing mendapatkan bagian dari buah yang dihasilkannya. Dalam hal ini terkandung dua hikmah yang sangat mulia yaitu :

a. Menghilangkan kemiskinan dari pundak orang miskin sehingga bisa mencukupi kebutuhan hidupnya. Dengan adanya aqad Musaqah maka penggarap bisa mencukupi kebutuhannya, karena kerja sama ini memperoleh bagi hasil di antara kedua belah pihak.

b. Saling tukar manfaat di antara manusia. Dengan aqad Musaqah ini manusia saling bertukar menfaat, dimana pemilik kebun bisa 
memanfaatkan tenaga penggarap dan penggarap atau pengelola bisa memanfaatkan kebun.

Di samping itu ada faedah bagi pemilik kebun, yaitu karena pemelihara atau penggarap sudah merawat pohon sampai besar dan berbuah atas jasanya. Kalau seandainya pohon itu dibiarkan begitu saja tanpa dikelola dan dirawat serta disirami tentu bisa mati dalam waktu singkat. Belum lagi ada faedahnya dari ikatan cinta dan kasih sayang sesama manusia, maka jadilah umat ini, umat yang bersatu dan bekerja untuk kemaslahatan. (Suhendi 2011, 150)

\section{METODOLOGI}

Jenis penelitian yang penulis lakukan adalah penelitian lapangan (field research) dengan menggunakan pendekatan metode kualitatif. Metode kualitatif yaitu metode penelitian yang berlandaskan pada filsafat postpositivisme, digunakan untuk meneliti pada kondisi obyek yang alamiah (sebagai lawannya adalah eksperimen) dimana peneliti adalah sebagai instrumen kunci, pengumpulan data dilakukan secara triangulasi (gabungan), analisis data bersifat induktif atau kualitatif, dan hasil penelitian kualitatif lebih menekankan makna dari pada generalisasi. Pendekatan kualitatif dapat juga diartikan bahwa suatu penelitian yang dilakukan dengan turun langsung ke lapangan untuk memperoleh data yang berkaitan dengan Sistem Bagi Hasil Kebun Aren Dalam Perspektif Ekonomi Syariah Di Nagari Andaleh Baruh Bukik Kecamatan Sungayang Kabupaten Tanah Datar.

Dalam melakukan penelitian ini, peneliti langsung jadi instrumen kuncinya dengan cara, peneliti langsung berada di lapangan untuk meneliti yaitu dengan melakukan wawancara. Kemudian untuk instrumen pendukungnya, peneliti menggunakan alat seperti handphone, field notes, daftar wawancara serta berupa dokumen seperti dokumen profil Nagari Andaleh Baruh Bukik jumlah pemilik dan penggarap pohon aren (enau) Nagari Andaleh Baruh Bukik.

Sumber data primer dalam penelitian ini adalah pemilik dan penggarap kebun aren, wawancara dengan Bapak Wali Nagari beserta Kaur Perekonomian Nagari Andaleh Baruh Bukik.

Sumber data sekunder dalam penelitian ini berupa dokumen-dokumen yang ada di Nagari Andaleh Baruh Bukik yang berkaitan langsung dengan penelitian seperti: dokumen profil Nagari Andaleh Baruh Bukik dan jumlah pemilik dan penggarap pohon aren (enau) Nagari Andaleh Baruh Bukik. Dokumentasi kegiatan kelompok tani gula aren Nagari Andaleh Baruh Bukik. (Sugiyono 2012, 146)

\section{PEMBAHASAN}

Pelaksanaan Sistem Bagi Hasil Pemilik Dan Penggarap Kebun Aren Dalam Perspektif Ekonomi Syariah Di Nagari Andaleh Baruh Bukik Kecamatan Sungayang Kabupaten Tanah Datar

Manusia dianjurkan untuk menggunakan kemampuan ataupun potensi yang ada di dalam dirinya, akan tetapi tidak bisa terlepas dari sumber daya alam yang tersedia dimana tempat ia tinggal. Dengan demikian, masyarakat Nagari Andaleh Baruh Bukik telah melakukan kegiatan-kegiatan ekonomi yang sesuai dengan kemampuan dan potensi serta sumber daya alam yang tersedia yaitu perdagangan, pertanian, dan Perkebunan. Dalam hal ini masyarakat Nagari Andaleh Baruh Bukik mengembangkan perkebunan aren sebagai salah satu sumber utama dalam peningkatan perekonomian mereka.

Perkebunan Aren (enau) memerlukan tenaga kerja cukup banyak, dan dinamika pekerjaannya sangat padat sehingga akan menghidupkan ekonomi masyarakat setempat. Keunggulan lainnya, usaha tani aren (enau) bisa dikombinasi dengan usaha yang lain di

27 Sistem Bagi Hasil Kebun Aren Dalam Perspektif Ekonomi Syariah Di Nagari Andaleh Baruh Bukik Kecamatan Sungayang Kabupaten Tanah Datar 
dalam areal yang sama secara terpadu dan juga masih menghasilkan kolang-kaling, ijuk, lidi, sagu, kayu dan lain lain. Keunggulan aren (enau) dari aspek lahan dan lingkungan, karena lahan yang dibutuhkan perkebunan dan industri gula aren lebih fleksibel dan mudah dibandingkan dengan penyediaan lahan untuk perkebunan tebu. (Dian Kusumanto, 2016: 150-170)

Hasil wawancara yang penulis lakukan dengan Bapak Dedi Syaputra selaku kepala Jorong Andaleh Baruh Bukik menyatakan bahwa ada dua kategori terhadap kebun aren (enau) ini. Pertama, menyadap aren sebagai gaya hidup, kedua; menjadikan kebun aren (enau) sebagai landasan dan sumber kehidupan utama keluarga. Sehingga di dalamnya terdapat aspek kesejahteraan, yang mana semakin banyak kebun arennya semakin tinggi pula tingkat kehidupan sosialnya di masyarakat. (Wawancara dengan Bapak Dedi Syaputra hari Senin tanggal 7 Januari 2021)

Lebih lanjut Bapak Supardi selaku Sekretaris Nagari Andaleh Baruh Bukik menjelaskan bahwa pembuatan gula aren diawali dari proses pengambilan air nira dari pohon aren (enau) yang disadap. Dari pohon aren (enau) yang disadap menghasilkan cairan yang disebut nira. Air nira aren (enau) kemudian dimasak dalam wajan besar hingga menjadi mengental dan berubah warnanya menjadi merah kecokelatan. Setelah dirasa cukup mengental dan dapat dicetak maka selesailah proses pemasakan air nira tersebut. Kemudian nira yang telah selesai dimasak maka dicetak berdasarkan ukuran yang telah disediakan dan pada saat beberapa jam kemudian maka gula aren yang dicetak tersebut telah siap untuk dikonsumsi atau diperjual belikan. Harga gula aren asli pada tingkat konsumen per kilogramnya dijual kisaran harga Rp.20.000,- sampai dengan Rp. 25.000. (Wawancara dengan Bapak Supardi pada hari Senin tanggal 7 Januari 2021)

Air nira kemudian dimasak dalam wajan besar hingga menjadi mengental dan berubah warnanya menjadi merah kecokelatan. Setelah dirasa cukup mengental dan dapat dicetak maka selesailah proses pemasakan air nira tersebut. Kemudian nira yang telah selesai dimasak maka dicetak berdasarkan ukuran yang telah disediakan dan pada saat beberapa jam kemudian maka gula aren yang dicetak tersebut telah siap untuk dikonsumsi atau diperjualbelikan. Setiap satu orang pembuat gula aren dapat menghasilkan kurang lebih sekitar 25 sampai dengan $40 \mathrm{~kg}$ gula aren. (Wawancara dengan Bapak Syafirman pada hari Senin tanggal 8 Januari 2021)

Menurut Bapak Ardianto dengan alamat Jorong Baruh Bukik sebagai pembuat gula aren sudah berjalan sekitar 8 tahun. Pengolahan pembuatan gula aren seperti pembuat gula aren pada umumnya. Diawali dari proses pengambilan air nira dari pohon aren yang disadap. Dari pohon aren yang disadap menghasilkan cairan yang disebut nira. Air nira aren kemudian dimasak dalam wajan besar hingga menjadi mengental dan berubah warnanya menjadi merah kecokelatan. Setelah dirasa cukup mengental dan dapat dicetak maka selesailah proses pemasakan air nira tersebut. Kemudian nira yang telah selesai dimasak maka dicetak berdasarkan ukuran yang telah disediakan dan pada saat beberapa jam kemudian maka gula aren yang dicetak tersebut telah siap untuk dikonsumsi atau diperjualbelikan. (Wawancara dengan Bapak Ardianto pada hari Selasa tanggal 8 Januari 2021)

Berdasarkan penjelasan Bapak Syawaldi tentang pengolahan air nira menjadi gula aren sebagaimana biasanya pembuat gula aren. Bapak Syawaldi mengambil air nira dari pohon aren yang ia miliki. Air nira yang diambil dari pohon kemudian dimasak hingga air nira berubah menjadi gula aren. Kemudian oleh pengepul gula aren tersebut dijual ke pasar atau ke warung-warung sehingga bisa sampai ke konsumen. Rata-rata harga pada konsumen untuk gula aren ada dua harga. Untuk gula aren asli dijual dengan harga Rp. 20.000,- sampai dengan Rp. 25.000,- per kilogramnya. (Wawancara dengan Bapak Syawaldi pada hari Selasa tanggal 8 Januari 2021) Untuk pembahasan dalam bagian ini penulis akan menyampaikan sistem bagi hasil kebun aren antara penggarap dan pemilik yang terjadi 
pada masyarakat Nagari Andaleh Baruh Bukik dengan maksud untuk mengetahui lebih jelas bagaimana masyarakat menggunakan sistem bagi hasil pertanian dan menerapkannya dalam kehidupan sehari-hari.

Berikut adalah bentuk-bentuk sistem bagi hasil kebun aren yang dipraktekan oleh masyarakat di Nagari Andaleh Baruh Bukik

a. Sistem bagi hasil Bapaduoan

Yang dimaksud dengan sistem hasil adalah pemilik kebun atau orang yang mempunyai kebun menyerahkan kebunnya kepada penggarap untuk dikelola. Adapun pembagian dari hasil pertanian sesuai dengan kesepakatan mereka antara pemilik dengan penggarap 50\% : 50\%. Dalam sistem ini biasanya semua peralatan ditanggung oleh penggarap atau pengelola sedangkan yang berkaitan dengan kebun seperti pupuk, obatobatan ditanggung oleh pemilik kebun. Sehingga dalam bagi hasil aren biasanya mereka bagi dua saja, seperti dalam sepekan (seminggu) misalnya dapat $100 \mathrm{~kg}$ gula aren, maka punya kebun atau lahan mendapatkan $50 \mathrm{~kg}$ dan penggarap pun mendapatkan $50 \mathrm{~kg}$ apabila memakai porsi nisbah 50\%:50\%.

Berdasarkan wawancara dengan Bapak jumak alamat Jorong Baruh Bukik dia sebagai penggarap menyataka bahwa kelebihan dari porsi 50\%:50\% bagi penggarap adalah penggarap cuman bisa menggarap gula aren saja tanpa mengurus pohon aren dari kecil sampai menghasilkan. Kekurangan porsi bagi hasil 50\%:50\% bagi penggarap yaitu dalam penggarapan gula aren yang mana penggarap harus mengambil sadapan nira itu setiap harinya tanpa memandang cuaca saat itu. Dan wawancara dengan Bapak Asril Jorong Baruh Bukik sebagai pemilik kebun aren dia menyatakan bahwa kelebihan dengan nisbah 50\%:50\% adalah pemilik bisa mendapatkan penghasilan dari gula aren yang sudah di produksi tanpa pemilik untuk menyadap nira kebatangnya. Kekurangan dari nisbah bagi hasil 50\%:50\% ini tidak ada cuman hasil yang dibagi kepenggarap itu sebanding yang dilakukan oleh penggarap. (Wawancara dengan Bapak Jumak dan Bapak Asril pada hari Rabu tanggal 10 Februari 2021)

Menurut Bapak Kubat dengan alamat Jorong Baruh Bukik merupakan salah satu penggarap gula aren di Nagari Andaleh Baruh Bukik. Beliau telah menjadi penggarap gula aren kurang lebih 10 tahun. Berdasarkan penjelasan Bapak Kubat dia selama seminggu mendapatkan $70 \mathrm{~kg}$ gula aren, yang mana perkilo gula aren dijual dengan harga Rp 20.000. Biaya pembuatan gula aren selama 1 bulan 500.000, penghasilannya selama sebulan $\mathrm{Rp}$ 2.800.000 tanpa dikurangi biaya-biaya. Bapak Kubat ini memakai bagi hasil 50\%:50\%. (Wawancara dengan Bapak Kubat pada hari Rabu tanggal 10 Februari 2021)

Namun jika selama penggarapan berjalan, tiba-tiba petani penggarap sakit atau ditimpa musibah, maka biasanya yang punya kebun menyuruh kerabat penggarap untuk menyadap aren dan hasilnya pun tetap dibagi separuh untuk yang pemilik kebun aren (enau) dan separoh lagi tergantung pada dua orang penggarap tersebut. Dan jika terjadi bencana alam seperti banjir atau kebakaran, maka penggarap tidak ada menanggung kerugian selama bencana itu terjadi tidak disebabkan oleh kelalaian penggarap.

b. Sistem Tolong Menolong

Dalam sistem ini pemilik kebun menyerahkan kebunnya kepada penggarap, namun tidak ditentukan bagi hasilnya. Penggarap boleh menyerahkan hasil kebun itu dalam sepekan berapa saja, karena dalam sistem ini sifatnya hanya tolong- menolong dan membantu sesama manusia.

Sistem ini terjadi biasanya pemilik kebun merasa kasihan melihat kondisi ekonomi petani penggarap sangat lemah atau rendah sehingga pemilik menyerahkan kebunnya untuk digarap dan juga biasanya terjadi karena pemilik kebun bertempat tinggal jauh dari lokasi kebunnya dan tidak jarang di antara mereka alasannya karena tidak mempunyai kesempatan untuk menggarapnya karena mempunyai pekerjaan lain seperti Pedagang, Pegawai BUMN, pegawai BUMD, Guru, Pegawai Negeri Sipil dan sebagainya. 
Misalnya Bapak Jamawar sebagai pemilik kebun aren (enau), Jamawar menyerahkan kebunnya kepada Syofiandi untuk di kelola dan dirawat agar jangan sampai kebun tersebut terlantar, Karena pemilik kebun tidak sempat mengurusnya pun pemilknya tidak bertempat tinggal di Nagari Andaleh Baruh Bukik. Kekurangan dari sistem tolong menolong ini tidak ada karena ini sistem yang dilakukan semata-mata untuk menolong keluarga yang kekurangan penghasilannya dan kelebihan dari sistem tolong menolong ini adalah bisa menolong keluarga yang kekurangan penghasilan. (Wawancara dengan Bapak Janawar pada hari Senin tanggal 7 Januari 2021)

Perlu dijelaskan bahwa pada sistem tolong-menolong ini agak berbeda dengan sistem bagi hasil sebelumnya, pada sistem ini dilatar belakangi semata-mata hanya untuk menolong penggarap, sistem ini lahir akibat adanya hubungan kekeluargaan antara pemilik dan penggarap kebun aren (enau).

c. Sistem Bagi hasil $(70 \%: 30 \%)$

Yang dimaksud dengan sistem bagi hasil 70\% : 30\% adalah dimana orang yang mempunyai kebun menyerahkan kebunnya kepada penggarap untuk dikelola. Adapun pembagiannya dibagi menurut kesepakatan yang disepakati yakni $70 \%$ dari hasil gula aren adalah bagian penggarap, sedangkan $30 \%$ dari hasil yang diperoleh adalah bagiannya pemilik kebun aren, misalnya dalam sepekan menghasilkan $120 \mathrm{~kg}$ aren, penggarap mendapatkan $80 \mathrm{~kg}$ gula aren, sedangkan pemilik kebun aren mendapakan $40 \mathrm{~kg}$ gula aren.

Wawancara dengan ketua Bundo Kanduang Nagari Andaleh Baruh Bukik periode 2016-2021 dia mengatakan bahwa selama pembagian hasil gula aren dengan nisbah 70\%:30\% ini tidak ada pertengkaran yang terjadi antara penggarap dan pemilik, cuman permasalahan yang terjadi antara penggarap dan pemilik di Nagari Andaleh Baruh Bukik yaitu terjadinya pembicaraan yang tidak senang atau tidak relanya setelah akad itu berjalan dikarenakan bagi hasil yang dilakukan itu cuma berlaku untuk produksi gula aren saja sedangkan untuk hasil produksi yang lain seperti buah tab, ijuk, dahan, dan batang pohon aren itu tidak dibagi hasil. (Wawancara dengan ketua Bundo Kandung Nagari Andaleh Baruh Bukik pada hari Rabu tanggal 10 Februari 2021)

Dari pernyataan ketua Bundo Kanduang Nagari Andaleh Baruh Bukik ini sebagaimana diketahui bahwa dalam sebuah transaksi bagi hasil kita harus rela sama rela sedangkan yang terjadi di masyarakat Nagari Andaleh Baruh Bukik terdapat tidak adanya kerelaan antara penggarap dan pemilik pohon aren sebagaimana yang terdapat dalam teori at-taradi.

Berdasarkan praktek yang terjadi di lapangan, dengan adanya pembagian hasil yang dilakukan antara pemilik dan penggarap kebun aren di Nagari Andaleh Baruh Bukik yang telah disepakati secara bersama mengandung gharar dan adanya ketidakadilan dalam pembagian hasil dari kebun aren (enau). Seharusnya setiap hasil yang diperoleh dari pohon aren (enau) penggarap harus menjelaskan secara rinci kepada pemilik tentang hasil yang diperoleh. Dari setiap hasil yang diperoleh pemilik juga berhak mendapatkan hasilnya.

Berdasarkan beberapa penjelasan di atas, maka dapat penulis kemukakan analisis datanya bahwa sistem bagi hasil yang terjadi pada petani kebun aren di Nagari Andaleh Baruh Bukik terdapat adanya kecurangan atau ketidakjujuran dari pihak penggarap kepada pemilik terhadap hasil yang diperoleh, di mana pihak pemilik hanya menerima pembagian dari penjualan gula aren saja. Sementara pihak penggarap disamping menerima bagian dari hasil penjualan gula aren ia juga mendapatkan hasil lain dari pohon aren (enau) yang ia kelola diantarannya (penjualan buah tab, penjualan ijuk, penjualan daun dan lidi dahan enau, penjualan batang enau) sehingga ada kemungkinan terjadi suatu tindakan yang telah merampas hak orang lain dalam bentuk ketidakadilan dalam pembagian hasil. 


\section{Penetapan Porsi Bagi Hasil Petani Dan Penggarap Kebun Aren Dalam Perspektif Ekonomi Syariah Di Nagari Andaleh Baruh Bukik Kecamatan Sungayang Kabupaten Tanah Datar}

Secara umum, Islam tidak hanya mengajarkan para umat-umatnya untuk memfokuskan diri pada hal-hal yang bersifat ibadah semata, namun juga menjadi panduan bagi manusia dalam berperilaku sehari-hari. Panduan tersebut secara garis besar diatur oleh Hukum Syariah. Salah satu bagian dari hukum syariah adalah muamalah. Hukum muamalah yaitu hukum-hukum yang mengatur hubungan seseorang dengan sejenisnya, seperti jual beli, sewa-menyewa, gadai menggadai, syirkah, utang piutang, dan hukum perjanjian.

Hukum-hukum tersebut mengatur hubungan perorangan, masyarakat, hal yang berhubungan dengan harta harta kekayaan, dan memelihara hak serta kewajiban masingmasing, oleh karena itu, membahas permasalahan tinjauan atau perspektif mengenai suatu hal, maka akan muncul berbagai macam tafsiran yang sepihak dan lebih subjektif. Terlebih jika membincangkan dari arah perspektif hukum syriah, akan mungkin sangat terjadi benturan terutama dengan realita yang terjadi di masyarakat. Hal inilah juga yang akan menjadi pertimbangan dalam menganalisis proses pelaksanaan bagi hasil gula aren pada nagari Andaleh Baruh Bukik menurut perspektif hukum syariah.

Bagi hasil dalam kegiatan ekonomi adalah bentuk return (perolehan dan pengembalian) dari kontrak kerja sama (dua orang atau lebih yang berakad) dan besarnya return bergantung pada hasil usaha yang dilakukan. Bagi hasil yaitu suatu sistem pengelolaan dana dalam perekonomian Islam, yakni pembagian hasil antara pemilik modal dan pengelola.

Mekanisme bagi hasil secara rasional dan objektif dapat menciptakan keadilan diantara kedua belah pihak yang mengadakan kerja sama. Kedua belah pihak memiliki peluang yang sama untuk mendapatkan keuntungan dan menanggung risiko apabila usaha mengalami kerugian. Didalam usaha diperjanjikan adanya pembagian hasil atas keuntungan yang akan didapat antara kedua belah pihak atau lebih. Besarnya suatu penentuan porsi bagi hasil antara kedua belah pihak ditentukan sesuai kesepakatan bersama dan harus terjadi dengan adanya kerelaan di masing-masing pihak tanpa adanya paksaan ( Karomah, 2010: 22). Dalam sistem Ekonomi syariah, aktifitasnya sangat menitik beratkan pada nilai-nilai yang terkandung dalam ajaran agama Islam yang bersumber dari Al-Quran pada surat Al-Baqarah ayat 188 yang artinya yaitu:

"Dan janganlah sebahagian kamu memakan harta sebahagian yang lain di antara kamu dengan jalan yang bathil dan (janganlah) kamu membawa (urusan) harta itu kepada hakim, supaya kamu dapat memakan sebahagian daripada harta benda orang lain itu dengan (jalan berbuat) dosa, Padahal kamu mengetahui".

Begitu juga halnya dengan sistem bagi hasil yang dilakukan oleh masyarakat Nagari Andaleh Baruh Bukik, yang mana pemilik kebun hanya menyediakan lahannya saja sedangkan mengenai alat pertaniannya disediakan oleh penggarap, kemudian hasilnya nanti akan dibagi dua sesuai dengan ketentuan yang telah diatur oleh kedua belah pihak. Sistem bagi hasil yang dilakukan oleh masyarakat Nagari Andaleh Baruh Bukik dimana bibit disediakan pemilik kebun sehingga penggarap hanya tinggal menggarapnya saja.

Adapun mengenai hal-hal yang mungkin terjadi selama penggarapan berlangsung seperti banjir atau kebakaran yang mana tidak terdapat ganti rugi, hal tersebut tidaklah membatalkan akad bagi hasil yang telah disepakati oleh pemilik dan penggarap. Sebab dalam sistem bagi hasil ini kedua pihak bersama-sama memberikan kontribusi, sehingga keduanya mendapat bagian dari hasil kebun begitu juga kerugiannya.

Adapun sistem tolong-menolong yang mana tujuan dasarnya adalah rasa kasihan dan saling membantu, maka sangat jelas kesesuaiannya dengan konsep ekonomi Islam, karena dalam Islam sendiri sangat dianjurkan untuk saling tolong-menolong antara sesama manusia dan bahkan tidak boleh membiarkan tetangganya atau saudaranya kelaparan 
sedangkan kita berkecukupan, sebagaimana yang terlampir dalam al-qur'an (QS. ALMa'idah :2) yang artinya yaitu:

"Dan tolong menolonglah kamu (mengerjakan) kebajikan dan taqwa, dan jangan tolong menolong dalam perbuatan dosa dan pelanggara. Dan bertawaqalah kamukepada Allah, sesungguhnya Allah amat berat siksaanya.

Sebagaimana yang telah diketahui bersama bahwa dalam Islam apabila seseorang memiliki kelebihan harta baik itu sedikit atau banyak, maka ia tidak boleh sewenangwenang dan membiarkan saudaranya terlantar. Karena dalam kepemilikan dan penggunaan harta, tidak semata untuk kepentingan pribadi, namun juga harus bisa memberikan manfaat dan kemaslahatan untuk orang lain.

Dalam sistem tolong-menolong yang di lakukan oleh masyarakat Nagari Andaleh Baruh Bukik ini tergolong ke sistem musaqah yang mana pada musaqah pihak kedua diberi kepercayaan untuk menjaga kebun dan mendapatkan bagian dari hasil kebun tersebut, begitu juga pada sistem tolong-menolong, penggarap diberi kepercayaan oleh yang pemilik kebun menjaga kebunnnya dan dia mendapatkan hasil dari hasil kebun tersebut.

Sistem bagi bagi hasil yang lebih dominan di lakukan oleh pemilik dan penggarap kebun aren adalah bagi hasil dengan porsi nisbah 70\%:30\% yang dilakukan oleh masyarakat Nagari Andaleh Baruh Bukik, dimana pemilik kebun mendapatkan 1/3 dari hasil kebun.

Berdasarkan wawancara penulis dengan Bapak Ardinal dengan alamat Jorong Baruh Bukik selaku pemilik lahan menjelaskan bahwa bagi hasil kebun aren dengan porsi nisbah 70\%:30 \% sering kali terjadi persoalalan yang disebabkan oleh ketidaksesuain apa yang di sepakati dari awal dengan hasil yang diperoleh antara pemilik dengan penggarap. Pemilik lahan merasa sering dirugikan dan dizalimi akibat penggarap yang lalai dengan kewajibanya. Kerugian yang dialami pemilik semakin bertambah karena penggarap gula aren menggunakan hasil dari air nira tersebut di produksi dalam bentuk lain yakni tuak yang secara jelas sangat di larang oleh Islam. (Wawancara dengan Bapak Ardinal pada hari Selasa tanggal 8 Januari 2021)

Kerugian yang dialami pemilik lahan semakin bertambah karena diketahui bahwa nira aren itu digunakan untuk tuak di dalam fikih masalah ini disebut sad dzari'ah. Sad AdzDzari'ah yaitu pelarangan atas apa saja yang pada dasarnya itu boleh dilakukan, agar dia tidak mengarah kepada yang tidak boleh untuk dilakukan. Metode sad adz-dzari'ah adalah sebuah metode yang bersifat preventif dalam rangka menjaga kemungkinan-kemungkinan buruk serta agar tidak terjadi hal-hal yang berdampak negatif.

Posisi metode ini dalam hukum Islam yaitu sebagai pengatur tentang perilaku perbuatan yang mengandung sebuah aspek hukum yang belum dilakukan manusia sebagai mukallaf dalam rangka menjaganya agar tidak terjatuh ke dalam dampak negatif ketika melakukannya.

Hal ini bukan berarti sebagai sebuah upaya pengekangan, akan tetapi karena memang salah satu tujuan hukum Islam yaitu untuk mewujudkan suatu kemaslahatan dan menghindari kerusakan. Jika suatu perbuatan yang belum dilakukan diduga keras akan menimbulkan kerusakan, maka dilaranglah hal-hal yang mengarahkan kepada perbuatan tersebut. Sebagai metode preventif, maka tampilan pertama metode ini adalah memagari dan menjaga atas berbagai kemungkinan buruk atau suatu kerusakan yang ditimbulkan ketika satu perbuatan itu dilakukan.

Beberapa contoh yang bisa dimunculkan terkait dengan metode ijtihad dalam sad $a d z-d z a r i ' a h$ ini adalah sebagai berikut:

1. Ketidakbolehan menggali sumur di jalanan umum, dikarenakan adanya mafsadah yaitu tergelincir dan jatuhnya orang lain.

2. Ketidakbolehan menjual buah anggur kepada pembuat khamer dikarenakan adanya mafsadah yaitu dikhawatirkan akan dibuat minuman yang memabukkan. 
3. Ketidakbolehan bagi kaum perempuan untuk menghentakkan kakinya ke atas, dikarenakan adanya mafsadah yaitu terlihatnya aurat yang harus ditutupi.

4. Ketidakbolehan untuk mencela dan atau mencaci Allah kaum musyrik, dikarenakan adanya mafsadah yaitu munculnya aksi pembalasan pencelaan terhadap Tuhan kaum muslim/mu' min itu sendiri.

5. Ketidakbolehan melakukan praktek nikah tahalli, dikarenakan adanya mafsadah yaitu pernikahan tersebut hanya untuk formalitas penghalalan bagi perempuan agar bisa menikah kembali dengan mantan suami yang sudah menceraikannya sebanyak 3 kali.

6. Ketidakbolehan untuk memperjualbelikan senjata di suatu daerah yang kondisinya adalah daerah konflik, dikarenakan adanya mafsadah yaitu memperluas dan memunculkan suasana yang tidak bisa kondusif, yaitu pertumpahan darah dan permusuhan. (Baroroh, 2017: 294-296)

Sebagaimana disebutkan di atas, bahwasanya masalah tentang air nira yang dijadikan tuak itu apabila pemilik mengetahui air nira itu akan dijadikan tuak oleh penggarap maka haram hukumnya dan pemilik akan berdosa. Hal yang sama juga di sampaikan oleh Bapak Usmil Yandi dengan alamat Jorong Baruh Bukik. Dalam praktik bagi hasil kebun aren di Nagari Andaleh Baruh Bukik telah terbukti adanya kecurangan, mulai dari kegiatan pengolahan nira menjadi gula aren, hasil lain yang diperoleh penggarap dari pohon aren (enau) yang dipeliharanya tidak disampaikan secara transparan kepada pemilik kebun Aren. (Wawancara dengan Bapak Usmil Yandi pada hari Selasa tanggal 8 Januari 2021). Dalam Ekonomi Islam terdapat norma, etika agama, dan perikemanusiaan yang menjadi landasan pokok, yaitu :
a. Larangan menjual atau memperdagangkan barang-barang yang diharamkan.
b. Bersikap benar, amanah dan jujur.
c. Menegakkan keadilan dan mengharamkan riba.
d. Menerapkan kasih sayang.
e. Menegakkan toleransi dan keadilan.

Berdasarkan penjelasan di atas, menurut penulis hendaknya penggarap memiliki sikap amanah dan jujur atas pembagian hasil dari pohon aren (enau) kepada pihak pemilik, supaya pemilik tidak merasa dirugikan atau dizalimi, baik dalam jangka waktu dekat ataupun dalam jangka waktu yang lama sebagai akibat dari perjanjian bagi hasil yang disepakati.

\section{KESIMPULAN}

Bagi hasil dilakukan antara pemilik dan penggarap gula Aren di Nagari Andaleh Baruh Bukik yang telah disepakati secara bersama mengandung gharar dan adanya ketidakadilan dalam pembagian hasil dari pohon aren (enau) karena seharusnya setiap hasil yang diperoleh dari pohon aren (enau) penggarap harus menjelaskan secara rinci kepada pemilik tentang hasil yang diperoleh. Setiap hasil yang diperoleh penggarap, pemilik juga berhak mendapatkan hasilnya seperti penjualan buah tab, penjualan ijuk, penjualan daun dan lidi dahan enau, dan penjualan batang enau. Oleh karena itu, ada kemungkinan terjadi suatu tindakan yang telah merampas hak orang lain dalam bentuk ketidakadilan dalam pembagian hasil secara keseluruhan.

\section{DAFTAR PUSTAKA}

Adinugraha, Hendri Hermawan. (2013). Norma Dan Nilai Dalam Ilmu Ekonomi Syariah, dalam Jurnal Media Ekonomi \& Teknologi Informasi Vol. 2 No.1, hal 56. 
Aryani, Dwi Septa. Rachmawati Yuni \& Seto Agung Anggoro (Dengan Pendekatan Hasil Penelitian). Ekonomi Syariah. Jakarta: Nusa Letera Inspirasi

Azzam Abdul, Aziz Muhammad. 2010. Fiqh Muamalat System Transaksi dalam Islam. Jakarta: AMZAH.

Baroroh, Nurdhin. (2017). Metamorfosis "Illat Hukum" Dalam Sad Adz-Dzari'ah Dan Fath AdzDzariah (Sebuah Kajian Perbandingan). Al-Mazahib, Volume 5, Nomer 2, Desember 2017

Darwis, R. (2016). Sistem Bagi Hasil Pertanian Pada Masyarakat Petani Penggarap Dikabupaten Gorontalo Perspektif Hukum Ekonomi Islam. Jurnal Al-Mizan Volume 12 Nomor 1 Juni 2016 ISSN 1907-0985 E ISSN 2442-8256, 8-10.

Dian Kusumanto. (2016). Jurnal Pertanian Tropik ISSN Online No : 2356-4725 Vol.3, No.2. Agustus 2016. (15) : 150- 170

Diana, I. N. (2008). Hadis-Hadis Ekonomi. Malang: UIN Malang.

Fachri.Y. dkk. (2002). Petani Usaha Kecil dan Koperasi Berwawasan Ekonomi Kerakyatan. Pekanbaru: Unri Perss.

Faruq, M. A. (2019). Analisis Sistem Ekonomi Pada Produksi Air Minum Kemasan Biofir Di UD.S umber MubarokahSidoarjo. $h t t p: / / w w w . g o o g l e . c o m / u r l$ ? sa=tEsource=webErct=jEurl=http://digilib.uinsby.ac.id/30596 /Eved=2ahUKEwiDmaK5YDsAhW7IEsFHUqgA_IQFjAAegQICRADEusg=AOvVaw0X fSCS_jmq2oLo9x27tnT, 1-2.

Hasanuddin, I. R. (2011). Fiqh Muamalah dan Aplikasinya. Jakarta: Lembaga Penelitian UIN Syarif Hidayatullah.

Huda, C. (2015). Ekonomi Islam . Semarang: CV Karya Abadi Jaya.

Islahiha, N. A., Frita , N., \& Maulana, R. (2019). Penerapan Sistem Perekonomian Syariah Dalam Mengatasi Kesenjangan Sosial Ekonomi Di Indinesia. Vol 3 No 2, Desember 2019, 87-88.

Karomah, Yaumiddin Umi. (2010). Usaha Bagi Hasil Antara Teori Dan Praktik. Sioarjo: Kreasi Kencana

Kartiko, A. (2019). Konsep Bagi Hasil Dalam Perspektif Islam. Indonesia Interdisciplinary Journal Of Economics (IIJSE) e-ISSN: 2621-606X Vol 2. No. 1.Juli 2019 , 1-19

Mardani, D. (2012). Figh Ekonomi Islam. Jakarta: Kencana.

Misanam, M. (2008). Ekonomi Islam. Jakarta: PT Raja Grafindo Persada.

Mubyarto. (1997). Ekonomi Rakyat, Program IDT dan Demokrasi Ekonomi Indonesia. Yogyakarta: Aditya Media.

Mughits, Abdul. (2017). Penerapan Prinsip at-Taradi dalam Akad-akad Muamalat. Jurnal Aplikasi Ilmu-ilmu Agama ISSN 1411-8777 Volume 17, Nomor 1, 2017

Muhammad. (2007). Prinsip-Prinsip Ekonomi Islam. Yogyakarta: Graha Ilmu.

Mursal, implementasi prinsip-prinsip ekonomi syariah: alternatif mewujudkan kesejahteraan berkeadilan. jurnal perspektif ekonomi darussalam Volume 1 Nomor 1, Maret 2015. Hal. 76.

Nabawi, I. (2009). Ekonomi Islam Perspektif Teori, Sistem, dan Aspek Hukum. Surabaya: Putra Media Nusantara.

Nazeri. (2016). Melihat Sistem Perekonomian Indonesia Dengan Perspektif Islam. JEBI (Jurnal Ekonomi dan Bisnis Islam)-Volume 1,No.1, Januari-Juni 2016, 2-6.

Poli, W.I.M. 2010. Tonggak-Tonggak Sejarah Pemikiran Ekonomi. Surabaya: Brilian Internasional, hal 19

Prasetyo, Yoyok. (2018). Ekonomi Syariah. Jakarta: Aria Mandiri Group

Rezekiah, R. R. (2015). Pengolahan Gula Aren (Arrenga Pinnata Merr) Di Desa Banua Hanyar Kabupaten Hulu Sungai Tengah. Jurnal Hutan Tropis Volume 3 No.3, Edisi November 2015, 268-271.

Sjahdeini, Sutan Remy. 2014. Perbankan Syariah Produk-produk dan Aspekaspek Hukumnya. Jakarta: Kencana Prenamedia Group

Sugiyono. (2012). Metode Penelitian Kuantitatif, Kualitatif Dan R $\mathcal{E}$ D. Bandung: CV alfabeta 
Suhendi, H. (2011). Fikih Muamalah. Jakarta: PT Gaja Grafindo Persada.

Syaikh al-Allamah Muhammad, dkk. (2013). Fiqih Empat Mazhab Terjemahan Rahmah ALUmmah FI Iktilaf al-a' immah.Bandung: Hasyimi

Taufan Adi Kurniawan, M. (2020). Sistem Informasi Akuntansi Dengan Pendekatan Simulasi. Jakarta: ISBN.

Wahab, W. (2016). Pengaruh Tingkat Bagi Hasil Terhadap Minat Menabung Di Bank Syariah. JEBI (Jurnal Ekonomi dan Bisnis Islam)-Volume 1, Nomor 2, Juli-Desember 2016, 168-169.

Wawancara dengan Masyarakat petani aren (enau) 20 Oktober 2020 di Nagari Andaleh Baruh Bukik.

Wawancara dengan Bapak Zaitul hari Sabtu tanggal 2 Januari 2021 di Nagari Andaleh Baruh Bukik

Wawancara dengan Bapak Ajis Wanto pada hari Selasa tanggal 8 Januari 2021 di Nagari Andaleh Baruh Bukik.

Wawancara dengan Bapak Albayani Dt. Paduko Besar hari Senin tanggal 7 Januari 2021 di Nagari Andaleh Baruh Bukik.

Wawancara dengan Bapak Ardi Yasman pada hari Senin tanggal 7 Januari 2021 di Nagari Andaleh Baruh Bukik.

Wawancara dengan Bapak Ardianto pada hari Selasa tanggal 8 Januari 2021 di Nagari Andaleh Baruh Bukik.

Wawancara dengan Bapak Ardinal pada hari Selasa tanggal 8 Januari 2021 di Nagari Andaleh Baruh Bukik.

Wawancara dengan Bapak Dedi Syaputra hari Senin tanggal 7 Januari 2021 di Nagari Andaleh Baruh Bukik.

Wawancara dengan Bapak Delfi Rianto pada hari Selasa tanggal 8 Januari 2021 di Nagari Andaleh Baruh Bukik.

Wawancara dengan Bapak Delfi Rianto pada hari Selasa tanggal 8 Januari 2021 di Nagari Andaleh Baruh Bukik.

Wawancara dengan Bapak Irbus dan Bapak Raja pada hari Rabu tanggal 10 Februari 2021.

Wawancara dengan Bapak Janawar pada hari Senin tanggal 7 Januari 2021 di Nagari Andaleh Baruh Bukik.

Wawancara dengan Bapak Kardi Naswir hari Selasa tanggal 8 Januari 2021 di Nagari Andaleh Baruh Bukik.

Wawancara dengan Bapak Kubat pada hari Rabu tanggal 10 Februari 2021.

Wawancara dengan Bapak Metuk pada hari Rabu tanggal 10 Februari 2021.

Wawancara dengan Bapak Metuk pada hari Rabu tanggal 10 Februari 2021.

Wawancara dengan Bapak Rismaizai hari Sabtu tanggal 2 Januari 2021 di Nagari Andaleh Baruh Bukik.

Wawancara dengan Bapak Sarpani hari Sabtu tanggal 2 Januari 2021 di Nagari Andaleh Baruh Bukik.

Wawancara dengan Bapak Supardi pada hari Senin tanggal 7 Januari 2021 di Nagari Andaleh Baruh Bukik.

Wawancara dengan Bapak Syafirman pada hari Senin tanggal 8 Januari 2021 di Nagari Andaleh Baruh Bukik.

Wawancara dengan Bapak Syawaldi pada hari Selasa tanggal 8 Januari 2021 di Nagari Andaleh Baruh Bukik.

Wawancara dengan Bapak Usmil Yandi pada hari Selasa tanggal 8 Januari 2021 di Nagari Andaleh Baruh Bukik.

Wawancara dengan Bapak Wanda hari Sabtu tanggal 2 Januari 2021 di Nagari Andaleh Baruh Bukik.

Wawancara dengan ketua Bundo Kandung Nagari Andaleh Baruh Bukik pada hari Rabu tanggal 10 Februari 2021 
Wawancara dengan masyarakat petani enau, 1 November 2020. Di Nagari Andaleh Baruh Bukik.

Zulkarnain. (2003). Membangun Ekonomi Rakyat Persepsi Tentang Pemberdayaan Ekonomi Rakyat. Yokyakarta: Adicita Karya Nusa. 